perties and Reduced Correlations for Gases", Gulf Publishing, Houston, Texas (1967)

2) Dymond, J. H. and E. B. Smith: "The Virial Coefficients of Gases", Clarendon Press, Oxford (1969)

3) Groenier, W. S. and G. Thodos: J. Chem. Eng. Data, 5, 285 (1960)

4) Hirshfelder, J. O., R. B. Bird and C. F. Curtiss: "Molecular Theory of Gases and Liquids", John Wiley \& Sons Inc. (1964)

5) Kaminishi, G. and T. Toriumi: Bulletin of the Chemical Research Institute of Non-Aqueous Solutions, Tohoku University, 10, 61 (1961)

6) Leach, J. W. and P.S. Chappelear and T. W. Leland: AIChE J., 14, 568 (1968)
7) Leland, T. W., J. S. Rowlinson and G. A. Sather: Trans. Faraday Soc., 64, 1447 (1968)

8) McGrashan, M. L. and D. J. B. Potter: Proc. Roy. Soc. (London), A267, 478 (1962)

9) Michels, A., E. Dumoulin and J. J. Th. van Dijk: Physica, 27, 886 (1961)

10) Prausnitz, J. M. and R. D. Gunn: AIChE J., 4, 430 (1958)

11) Reamer, H. H. and B. H. Sage: J. Chem. Eng. Data, 4, 303 (1959)

12) Reed, T. M. and K. E. Gubbins: "Applied Statistical Mechanics", McGraw-Hill Inc. (1973)

13) Sarashina, E., Y. Arai and S. Saito: J. Chem. Eng. Japan, 6, 120 (1973)

14) Vennix, A. J. and R. Kobayashi: AIChE J., 15, 926 (1969)

\title{
MINIMUM TRANSPORT VELOCITY FOR HORIZONTAL PNEUMATIC CONVEYING*
}

\author{
SHIGERU MATSUMOTO, MichIO HARA, \\ Shozaburo SAITO AND Siro MAEDA \\ Department of Chemical Engineering, Tohoku University, Sendai
}

\begin{abstract}
The minimum transport velocity, that is, the mean air velocity required to prevent the settling of particles on the bottom of a horizontal pipe, was experimentally studied for granular particles. Two pipe sizes were used, $26 \mathrm{~mm}$ and $49 \mathrm{~mm}$ diameter, and 14 groups of solid particles ranging from $0.3 \mathrm{~mm}$ to $2 \mathrm{~mm}$ diameter were used. A general correlation for minimum transport velocity was obtained including density and size of solid particles and pipe diameter. The saltation point, at which the flow pattern changed from suspension flow to sliding flow, was also correlated on the basis of a simple theoretical consideration.
\end{abstract}

\section{Introduction}

In the operation of conventional pneumatic conveying systems, it is desirable to operate at as low an air flow rate as possible from the point of view of energy requirements, pipe erosion and particle attrition.

If, however, the air flow rate is reduced past a certain value, it leads to unstable operation and the possibility of blockage of the pipe. This critical air flow rate is called the minimum transport velocity.

The minimum transport velocity, that is, the mean air velocity required to prevent the settling out of particles and the accumulation of a layer of stationary or sliding particles on the bottom of a horizontal pipe, is of vital practical importance to designers.

Probably because of the difficulty of experiment on the minimum transport velocity, little work on

\footnotetext{
* Received on December 21, 1973

Presented at Tohoku Meeting (at Sendai, Aug. 1972) and

Tohoku Meeting (at Hirosaki, Oct. 1973) of The Soc. of Chem.

Engrs., Japan

干980 仙台市荒巻字青葉

東北大学工学部化学工学科、松本 繁
}

this problem has been reported, and a method of predicting minimum transport velocity for a given system has not as yet been established. Thus, in practice, conventional pneumatic conveying systems are still designed on the basis of operating experience.

In this paper, minimum transport velocities for horizontal pneumatic conveying are correlated for granular particles greater than 200 microns.

\section{Experimental Apparatus and Procedure}

A schematic diagram of the horizontal conveying line in the investigation is shown in Fig. 1. As conveying line, two Pyrex glass pipes were used; one was an $11 \mathrm{~m}$ length of $26 \mathrm{~mm}$ I.D. and the other was a $26 \mathrm{~m}$ length of $49 \mathrm{~mm}$ I.D. To cancel the end effect arising from bend or recycling line placed at the end of the test section, the conveying line, which consisted solely of straight pipe, was directly connected to the cyclone or separator.

Earlier studies seem to have neglected the problem of end effects. In most cases bends or vertical conveying line, for instance, are constructed behind the test section. In this investigation, we gave careful 


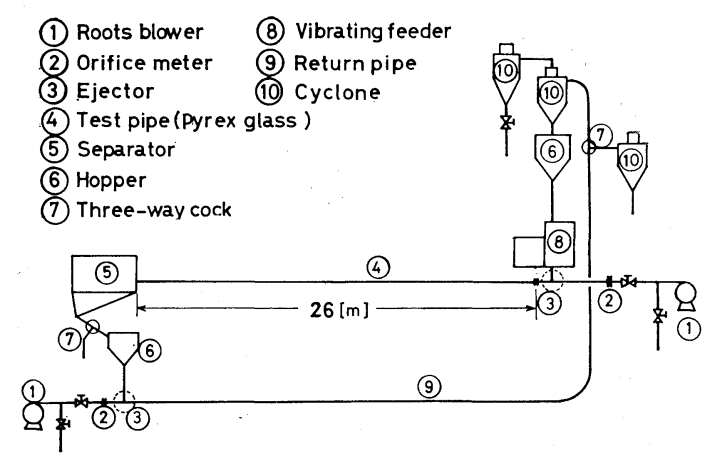

Fig. 1 Schematic diagram of experimental apparatus for a 49-mm I.D. pipe

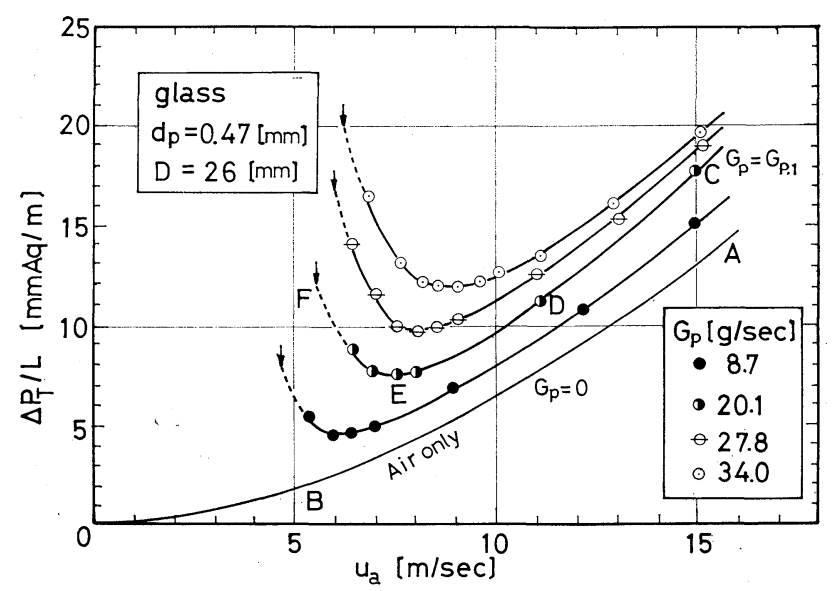

Fig. 2 Relations between pressure drop and air velocity with parameter of solids flow rate

\begin{tabular}{|c|c|c|c|c|c|c|c|}
\hline \multirow[b]{2}{*}{$\begin{array}{r}D \\
{[\mathrm{~mm}]}\end{array}$} & \multicolumn{6}{|c|}{ Table 1 Properties of solid particles } & \multirow[b]{2}{*}{$\mathrm{Ke}$} \\
\hline & Materials & $\begin{array}{c}\rho_{p} \\
{\left[\mathrm{~g} / \mathrm{cm}^{3}\right]}\end{array}$ & $\begin{array}{c}d_{p} \\
{[\mathrm{~mm}]}\end{array}$ & $\begin{array}{c}\text { Standard } \\
\text { deviation } \\
\text { [mm] }\end{array}$ & $\begin{array}{c}u_{t} \\
{[\mathrm{~m} / \mathrm{sec}]}\end{array}$ & $\begin{array}{l}F r_{p} \\
{[-]}\end{array}$ & \\
\hline \multirow{3}{*}{26} & glass & 2.5 & $\begin{array}{l}0.47 \\
1.00 \\
1.30\end{array}$ & $\begin{array}{l}0.030 \\
0.079 \\
0.070\end{array}$ & $\begin{array}{l}3.66 \\
7.67 \\
8.74\end{array}$ & $\begin{array}{l}53.90 \\
77.47 \\
77.41\end{array}$ & $\begin{array}{l}\phi \\
\varnothing \\
\odot\end{array}$ \\
\hline & copper & 8.7 & $\begin{array}{l}0.29 \\
0.55\end{array}$ & $\begin{array}{l}0.023 \\
0.059\end{array}$ & $\begin{array}{l}5.18 \\
9.83\end{array}$ & $\begin{array}{r}97.19 \\
133.92\end{array}$ & 市 \\
\hline & polystyrene & 1.0 & $\begin{array}{l}0.96 \\
2.10\end{array}$ & $\begin{array}{l}0.063 \\
0.290\end{array}$ & $\begin{array}{l}4.05 \\
7.02\end{array}$ & $\begin{array}{l}46.39 \\
48.92\end{array}$ & $\begin{array}{l}\text { 口 } \\
\text { 的 }\end{array}$ \\
\hline \multirow{3}{*}{49} & glass & 2.5 & $\begin{array}{l}0.48 \\
1.02 \\
1.64\end{array}$ & $\begin{array}{l}0.049 \\
0.093 \\
0.182\end{array}$ & $\begin{array}{l}3.74 \\
7.74 \\
9.82\end{array}$ & $\begin{array}{l}54.12 \\
77.40 \\
77.46\end{array}$ & \\
\hline & copper & 8.7 & $\begin{array}{l}0.30 \\
0.52 \\
0.76\end{array}$ & $\begin{array}{l}0.055 \\
0.083 \\
0.117\end{array}$ & $\begin{array}{l}5.36 \\
9.29 \\
4.52\end{array}$ & $\begin{array}{r}98.89 \\
130.11 \\
144.50\end{array}$ & $\downarrow$ \\
\hline & polystyrene & 1.0 & 1.07 & 0.063 & 4.52 & 44.14 & - \\
\hline
\end{tabular}

attention to this point.

Air was supplied from a Roots blower via an orifice meter to the test section. Solid particles were continuously fed from the hopper through the vibrating feeder to the inlet section. An ejector was constructed in the solids inlet section to ensure good dispersion in the pipe. The air and solids were separated in the cyclone or separator. The solids were returned to the hopper through another conveying line. A three-way cock was placed behind the separator to allow samples to be collected over a measured period of time for determination of the solids rate. Pressure taps were provided at about $1 \mathrm{~m}$ intervals along the conveying line. Making allowance for the region of acceleration of the particles, the pressure gradients of fully developed flow were measured in a section more than $8 \mathrm{~m}$ distant from the feed point in the case of $26 \mathrm{~mm}$ I.D. pipe and in a section more than $16 \mathrm{~m}$ distant in the case of $49 \mathrm{~mm}$ I.D. pipe.

The experiment was carried out by reducing the air velocity at a constant solids rate until the particles began to settle out on the bottom of the pipe. Physical properties of solids used in this investigation are shown in Table 1. The particles were spherical shaped particles and were sieved with Tyler standard screens. For the determination of the representative particle diameter, about 1000 particles were sampled randomly from each group of particles and the particle diameter was measured under a microscope. The median size in the particle-size distribution was taken as the representative size. Terminal velocities in Table 1 were calculated assuming spherical particles.

\section{Experimental Results and Discussion}

\section{1 Pressure drop and flow characteristics}

Typical plots are shown in Fig. 2 of pressure drop per unit length of pipe versus superficial air velocity with parameters of constant solids flow rate. In this figure, the line $\mathrm{AB}$ labelled $G_{p}=0$ represents the Fanning friction loss for the fluid medium alone flowing through the pipe.

When the superficial air velocity is slowly reduced from the value at point $\mathrm{C}$ to that at point $\mathrm{D}$ at a constant solids rate $G_{p, 1}$, the pressure drop decreases nearly parallel to that of the fluid medium alone. In this case the particles flow in suspension, dispersing uniformly in the pipe. Simultaneously, the velocity of the particles also decreases while the density or concentration of particles per unit length or volume of tube increases.

When the gas velocity is reduced further from the value at point $\mathrm{D}$, some of the particles begin to slide on the bottom of the pipe and a heterogeneous flow is observed. The pressure drop per unit length shows a minimum value at point E. Around this point, almost all the particles slide on the bottom, although a settled layer has not as yet appeared.

If the gas velocity is further reduced from point $\mathrm{E}$ to point $F$, the pressure drop increases rapidly. Finally, at point $F$, the particles begin to settle on the bottom of the pipe and a stationary bed is formed. The solids rate $G_{p, 1}$ represents the saturation carrying capacity of the fluid at the velocity at point $\mathrm{F}$. 


\begin{tabular}{|c|c|c|c|c|c|}
\hline Materials & $\begin{array}{c}d_{p} \\
{[\mathrm{~mm}]}\end{array}$ & $\begin{array}{l}F r_{s} \\
{[-]}\end{array}$ & $\begin{array}{l}m_{s} \\
{[-]}\end{array}$ & $\begin{array}{l}F r_{c} \\
{[-]}\end{array}$ & $\begin{array}{c}m_{c} \\
{[-]}\end{array}$ \\
\hline \multicolumn{6}{|l|}{$D=26 \mathrm{~mm}$} \\
\hline & 0.17 & $\begin{array}{l}11.1 \\
12.0 \\
15.3 \\
17.2\end{array}$ & $\begin{array}{l}2.0 \\
3.7 \\
5.9 \\
6.6\end{array}$ & $\begin{array}{r}9.5 \\
10.2 \\
11.4 \\
13.6\end{array}$ & $\begin{array}{l}2.4 \\
4.4 \\
7.9 \\
8.3\end{array}$ \\
\hline glass & 0.47 & $\begin{array}{l}11.7 \\
14.9 \\
15.9 \\
17.4\end{array}$ & $\begin{array}{l}2.4 \\
4.2 \\
5.4 \\
6.2\end{array}$ & $\begin{array}{r}9.5 \\
11.5 \\
12.3 \\
12.3\end{array}$ & $\begin{array}{l}2.9 \\
5.4 \\
7.0 \\
8.6\end{array}$ \\
\hline glass & 1.00 & $\begin{array}{l}12.1 \\
13.8 \\
14.7 \\
19.8 \\
22.8\end{array}$ & $\begin{array}{l}1.4 \\
2.1 \\
3.4 \\
5.5 \\
6.9\end{array}$ & $\begin{array}{l}10.9 \\
12.8 \\
14.1 \\
16.1 \\
18.0\end{array}$ & $\begin{array}{l}1.5 \\
2.2 \\
3.4 \\
6.6 \\
8.6\end{array}$ \\
\hline \multirow[t]{2}{*}{ glass } & 1.30 & $\begin{array}{l}15.9 \\
19.8 \\
21.4\end{array}$ & $\begin{array}{l}3.1 \\
4.2 \\
5.5\end{array}$ & $\begin{array}{l}14.6 \\
18.2 \\
19.6\end{array}$ & $\begin{array}{l}3.4 \\
5.0 \\
6.0\end{array}$ \\
\hline & & 22.4 & 5.8 & 20.8 & 6.5 \\
\hline copper & 0.29 & $\begin{array}{l}17.6 \\
19.2 \\
22.4\end{array}$ & $\begin{array}{l}3.8 \\
5.4 \\
8.5\end{array}$ & $\begin{array}{l}15.7 \\
16.4 \\
18.6\end{array}$ & $\begin{array}{r}4.2 \\
6.3 \\
10.3\end{array}$ \\
\hline copper & 0.55 & $\begin{array}{l}18.6 \\
20.8 \\
22.8 \\
24.8 \\
26.9\end{array}$ & $\begin{array}{l}3.5 \\
4.6 \\
5.8 \\
6.7 \\
8.1\end{array}$ & $\begin{array}{l}18.3 \\
19.5 \\
20.4 \\
22.1 \\
23.2\end{array}$ & $\begin{array}{l}3.6 \\
4.9 \\
6.5 \\
7.6 \\
9.5\end{array}$ \\
\hline \multirow[t]{2}{*}{ polystyrene } & 0.96 & $\begin{array}{l}12.9 \\
15.8 \\
17.6\end{array}$ & $\begin{array}{l}2.1 \\
3.3 \\
4.0\end{array}$ & $\begin{array}{l}10.4 \\
12.5 \\
13.8\end{array}$ & $\begin{array}{l}2.6 \\
4.2 \\
5.1\end{array}$ \\
\hline & & 19.7 & 5.3 & 14.8 & 7.0 \\
\hline \multirow[t]{2}{*}{ polystyrene } & 2.10 & 15.0 & 2.2 & 14.1 & 2.3 \\
\hline & & $\begin{array}{l}16.9 \\
20.1 \\
20.8\end{array}$ & $\begin{array}{l}3.0 \\
3.3 \\
4.0\end{array}$ & $\begin{array}{l}15.4 \\
16.4 \\
16.4\end{array}$ & $\begin{array}{l}3.3 \\
4.1 \\
5.1\end{array}$ \\
\hline \multicolumn{6}{|l|}{$D=49 \mathrm{~mm}$} \\
\hline \multirow[t]{3}{*}{ glass } & 0.48 & $\overline{10.4}$ & $\overline{1.0}$ & $\begin{array}{l}7.9 \\
9.1\end{array}$ & $\begin{array}{l}0.7 \\
1.2\end{array}$ \\
\hline & & 12.3 & 1.5 & 11.0 & 1.7 \\
\hline & & 13.6 & 2.0 & 11.4 & 2.3 \\
\hline \multirow[t]{4}{*}{ glass } & 1.02 & - & - & 9.5 & 0.7 \\
\hline & & 二 & - & $\begin{array}{l}11.5 \\
11.8\end{array}$ & $\begin{array}{l}2.1 \\
1.4\end{array}$ \\
\hline & & 13.9 & 2.3 & 13.0 & 2.5 \\
\hline & & 14.9 & 2.5 & 14.3 & 2.6 \\
\hline \multirow[t]{4}{*}{ glass } & 1.64 & - & - & 9.7 & 0.6 \\
\hline & & - & - & 12.7 & 0.9 \\
\hline & & - & - & 14.0 & 1.3 \\
\hline & & - & - & 15.3 & 1.5 \\
\hline \multirow[t]{5}{*}{ copper } & 0.30 & - & - & 15.6 & 1.7 \\
\hline & & $\overline{15.3}$ & $\overline{2.4}$ & $\begin{array}{l}12.1 \\
14.3\end{array}$ & $\begin{array}{l}1.6 \\
2.6\end{array}$ \\
\hline & & 16.0 & 2.8 & 14.3 & 3.2 \\
\hline & & 19.6 & 3.4 & 16.2 & 4.3 \\
\hline & & 20.6 & 4.4 & 16.9 & 5.4 \\
\hline \multirow[t]{4}{*}{ copper } & 0.52 & - & - & 13.3 & 0.8 \\
\hline & & 17.3 & 1.8 & 16.6 & 1.9 \\
\hline & & 20.5 & 2.9 & 19.2 & 3.1 \\
\hline & & 25.0 & 4.1 & 21.5 & 4.8 \\
\hline \multirow[t]{2}{*}{ copper } & 0.76 & - & - & 19.3 & 2.2 \\
\hline & & $\begin{array}{l}22.9 \\
25.5\end{array}$ & $\begin{array}{l}2.9 \\
3.1\end{array}$ & $\begin{array}{l}21.9 \\
23.1\end{array}$ & $\begin{array}{l}3.0 \\
3.5\end{array}$ \\
\hline \multirow[t]{3}{*}{ polystyrene } & 1.07 & - & - & 6.9 & 0.5 \\
\hline & & 9.2 & 0.7 & 8.1 & 0.8 \\
\hline & & 11.1 & 1.1 & 9.0 & 1.4 \\
\hline
\end{tabular}

That is, the gas velocity at this point corresponds to the minimum transport velocity for the solids rate $G_{p, 1}$. In this experiment, the minimum transport velocity was determined by visual inspection.

The point $\mathrm{E}$, at which the pressure drop has a minimum value, is regarded as one of the criteria that represent limiting conditions for the safety transport

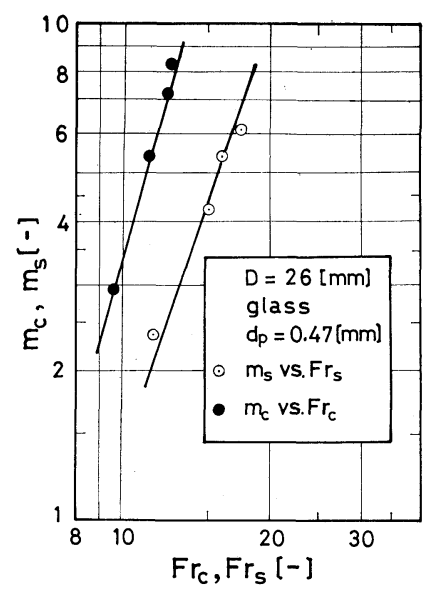

Fig. 3 Plots of $m_{s}$ vs. $F r_{s}$ and $m_{c}$ vs. $F r_{c}$ at a constant solids flow rate

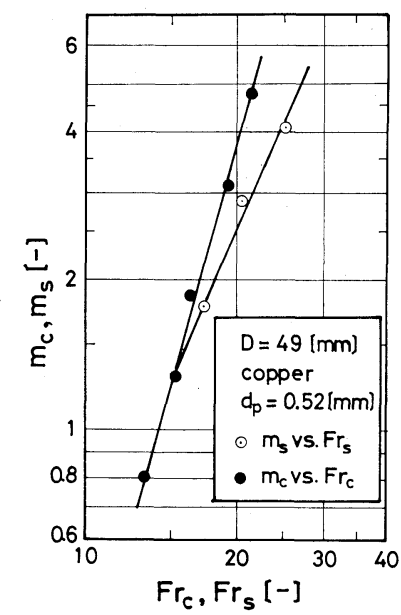

Fig. 4 Plots of $m_{s}$ vs. $F r_{s}$ and $m_{c}$ vs. $F r_{c}$ at a constant solids flow rate

of solids. In this paper, it is called the saltation point, to distinguish it from the saturation carrying capacity. Froude number and mass flow ratio at the minimum point are respectively represented as $F r_{s}$ and $m_{s}$. On the other hand, Froude number and mass flow ratio at the minimum transport velocity are respectively represented as $F r_{c}$ and $m_{c}$.

Experimental results are summarized in Table 2. In Figs. 3 and 4, examples of observed values of saltation velocity and minimum transport velocity are shown.

Generally, in the case of particles of low densities and small diameters, that is, particles of small terminal velocities, a stationary bed was not easily formed even if the minimum point was overshot. On the other hand, for particles having large terminal velocities, there were some cases when settling occurred before the minimum point was reached.

As far as pipe diameter was concerned, at constant solids rate the difference between saltation velocity and minimum transport velocity was smaller in the case of a $49 \mathrm{~mm}$ I.D. pipe than in the case of a 


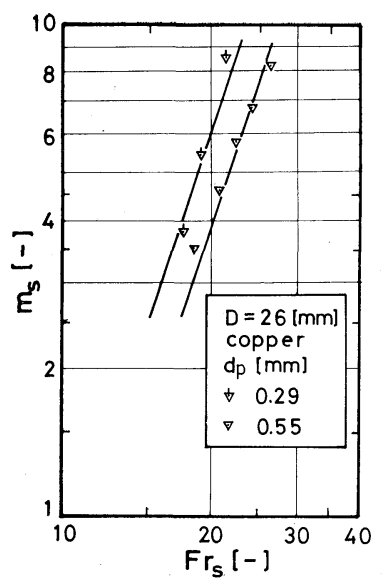

Fig. 5 Plots of $m_{s}$ vs. $F r_{s}$ at a constant solids flow rate

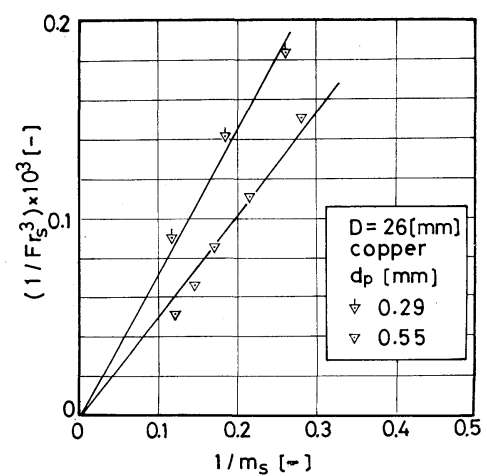

Fig. 6 Relations between $1 / m_{s}$ and $1 / F r_{s}{ }^{3}$

$26 \mathrm{~mm}$ I.D. pipe. Particularly when a $49 \mathrm{~mm}$ I.D. pipe was used and the solids flow rate was relatively small, it was often observed that settling occurred before the pressure drop showed a minimum value.

\section{2 Analytical study of saltation point}

The total pressure drop in fully developed horizontal gas-solids two-phase flow, $\Delta P_{T}$, is assumed to be expressed by the following equation.

$$
\Delta P_{T}=\Delta P_{a}+\Delta P_{h}+\Delta P_{s f}
$$

where $\Delta P_{a}$ is the pressure drop due to fluid friction and is given by

$$
\Delta P_{a} / L=2 f_{a} \rho_{a} u_{a}^{2} / g_{c} D
$$

The second term of Eq. (1), $\Delta P_{h}$, is the pressure drop required for allowing the particles to be suspended. If it is assumed that particles fall with a velocity $v_{p}$, this is 'given by

$$
\frac{\Delta P_{h}}{L}=\frac{G_{p} v_{p}}{u_{p}} \cdot \frac{1}{Q_{a}} \cdot \frac{g}{g_{c}}
$$

The velocity $v_{p}$ is assumed to be given by

$$
v_{p}=c_{0} u_{t}
$$

where $u_{t}$ is the terminal velocity of the particle. Substituting Eq. (4) into Eq. (3), $\Delta P_{h} / L$ is given by

$$
\Delta P_{h} / L=c_{0} m \rho_{a}\left(u_{t} / u_{p}\right) \cdot\left(g / g_{c}\right) \text {. }
$$

The third term, $\Delta P_{s f}$, is the pressure drop due to the friction between particles and pipe wall. This is given by

$$
\Delta P_{s f} / L=2 f_{p} \rho_{d s} u_{p}^{2} / g_{c} D=2 f_{p} \rho_{a} m u_{a} u_{p} / g_{c} D
$$

The ratio of particles and air velocity, $\varphi$, is given by

$$
\varphi=u_{p} / u_{a}
$$

Substituting Eq. (7) into Eqs. (5) and (6), Eq. (1) becomes

$$
\frac{\Delta P_{T}}{L}=\left(\frac{2 f_{a} \rho_{a}}{g_{c} D}\right) \cdot u_{a}^{2}+\left(\frac{c_{0} u_{t} g}{A \varphi g_{c}}\right) \frac{G_{p}}{u_{a}^{2}}+\left(\frac{2 f_{p} \varphi}{g_{c} D A}\right) G_{p} u_{a}
$$

Eq. (8) represents a curve which has a minimum point for a superficial air velocity with a parameter of $G_{p}$ as shown in Fig. 2. The minimum point of Eq. (8) corresponds to the saltation point defined in the above section. The condition for a minimum point at a constant solids flow rate is obtained as follows:

$$
1 / F r_{s}^{3}=\left(2 f_{a} \varphi / c_{0} F r_{t}\right)\left(1 / m_{s}+f_{p} \varphi / 2 f_{a}\right)
$$

where $f_{a}, c_{0}, f_{p}$ and $\varphi$ are assumed to be constant.

When $1 / m_{s} \gg f_{p} \varphi / 2 f_{a}$, that is, in the dilute phase, Eq. (9) is expressed approximately by

$$
1 / F r_{s}^{3}=\left(2 f_{a} \varphi / c_{0} F r_{t}\right) \cdot 1 / m_{s}
$$

When $1 / m_{s} \ll f_{p} \varphi / 2 f_{a}$, in the dense phase, Eq. (9) is approximated by

$$
1 / F r_{s}^{3}=f_{p} \varphi^{2} / c_{0} F r_{t}
$$

In this case, saltation velocity is determined by the physical properties alone, independent of mass flow ratio.

\section{3 Experimental results and analysis}

(1) Saltation point (minimum point in the pressure drop curve)

Figure 5 shows the relationship between $\mathrm{Fr}_{s}$ and $m_{s}$ at saltation point for copper beads. As shown in Fig. 5, the mass flow ratio at the saltation point was approximately related to the Froude number, $F r_{s}$, as follows: $m_{s} \propto F r_{s}^{3}$. The saltation point was thus found to satisfy the relation of Eq. (10). To confirm this, the relation between $1 / m_{s}$ and $1 / F^{3} r_{s}^{3}$ is shown in Fig. 6. From this figure, it is found that the extrapolated value of $1 / \mathrm{Fr}_{s}^{3}$ is nearly zero when $1 / \mathrm{m}_{s}$ approaches zero, and the second term of Eq. (9) is negligible. Therefore, we considered that the experimental results for saltation points were correlated in the form of Eq. (10), and obtained the following correlation:

$$
m_{s}=0.448\left(\rho_{p} / \rho_{a}\right)^{0.50} \cdot\left(F r_{p} / 10\right)^{-1.75} \cdot\left(F r_{s} / 10\right)^{3.0}
$$

where indices and factor of Eq. (12) were determined by the least squares-method.

To see to what extent the experimental data can be correlated with this equation, the relation between $m_{s, \text { exp }} /\left[0.448\left(\rho_{p} / \rho_{a}\right)^{0.50}\left(F r_{p} / 10\right)^{-1.75}\right]$ and $F r_{s}$ is plotted in Fig. 7. All the points are seen to lie within $\pm 40 \%$. 


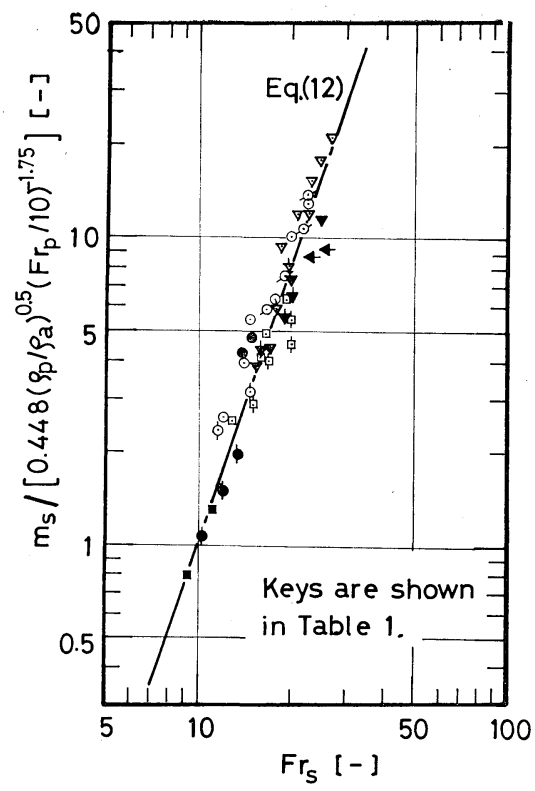

Fig. 7 Correlation of saltation point at a constant solids flow rate

However, saltation points, which were obtained by experiment with a constant air velocity, could not be correlated well by Eq. (12), though these were not mentioned in this paper.

(2) Minimum transport velocity

Relations between minimum transport velocity and mass flow ratio are shown in Fig. 8. These relations were considered to be controlled by the same factor as that in the case of saltation point. From the data, as shown in Fig. 9, the following correlation was obtained:

$$
m_{c}=0.373\left(\rho_{p} / \rho_{a}\right)^{1.06}\left(F r_{p} / 10\right)^{-3.70}\left(F r_{c} / 10\right)^{3.61}
$$

where indices and the factor of Eq. (13) were determined by the least-squares method.

Although the error of $\pm 50 \%$ appears to be not small at first sight, it seems to be unavoidable, because there are many indefinite factors in this type of experiment. There are, however, many cases when designers require the minimum transport velocity under a given solids flow rate. In these cases, the minimum transport velocity can be calculated within $\pm 20 \%$ error by Eq. (13). It is interesting that the minimum transport velocity is also correlated in the same form as Eq. (12), and the indices differ only slightly. The minimum transport velocity is thus considered to be closely related to the saltation velocity.

\section{4 Comparison with literature}

\section{(1) Saltation velocity}

Few reports have been published to date which draw a clear distinction between the starting point of settling and the minimum point of the pressure drop curve with a constant solids flow rate.

Welschof (1962) ${ }^{11)}$ and Siegel (1970) ${ }^{9 /}$ have reported

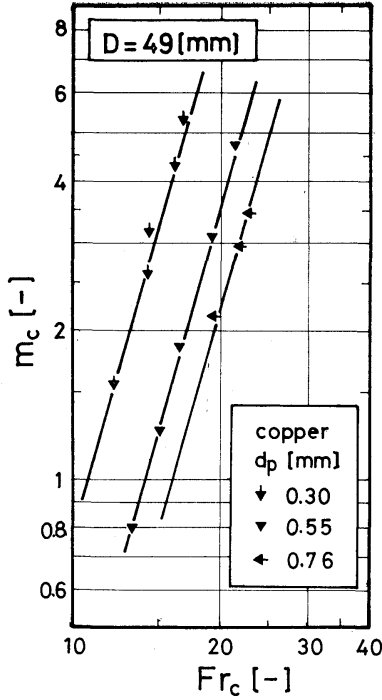

Fig. 8 Plots of $m_{c}$ vs. $F r_{c}$

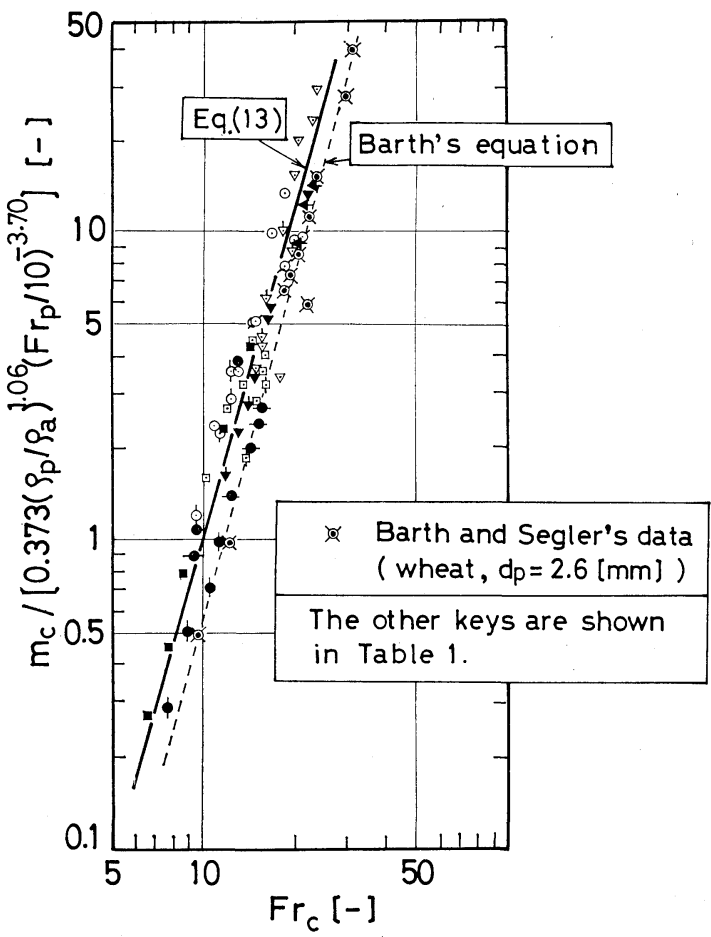

Fig. 9 Correlation of minimum transport velocity

pressure drop curves at a constant solids flow rate. These data were compared with the present correlation of saltation velocity, that is, Eq. (12). Welschof studied transport of wheat with a $44.5 \mathrm{~mm}$ I.D. pipe. Siegel observed pressure drop for 11 species of solids with four pipes. The degree to which their data could be correlated with Eq. (12) was investigated, the values of minimum points being read off the graph. Comparison of their data with Eq. (12) is shown in Fig. 10. From this figure, it can be seen that their data show somewhat smaller values than does this correlation. This is probably due to an end effect, arising from, for example, a bend placed at the end of the test section, and to the difference of quality 


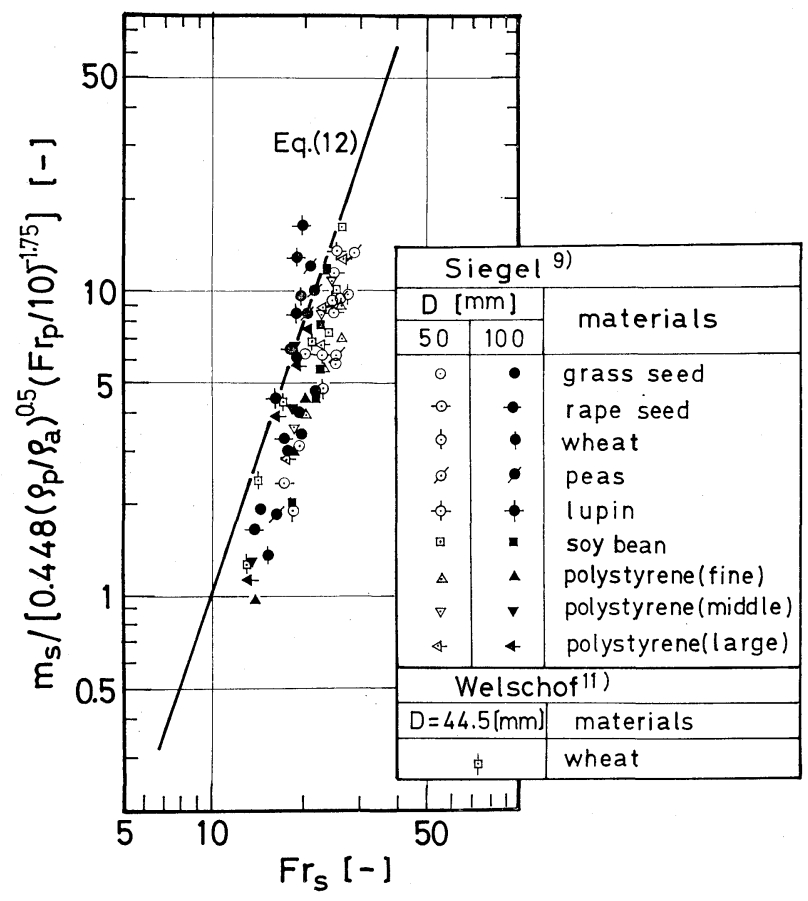

Fig. 10 Comparison of Eq. (12) with literature

of transparent pipe. Although the experiments of both Welschof and Siegel did not take the end effect into account, it is interesting that all their data were correlated within $-75 \%$ by Eq. (12).

(2) Minimum transport velocity

Equations of minimum transport velocity have been reported up to now by Barth $(1954)^{1}$, Guenther $(1957)^{5)}$, Thomas $(1962)^{10)}$, Doig and Roper $(1963)^{3)}$, Bohnet $(1965)^{2}$, Rose and Duckworth $(1968)^{7}$, and Duckworth $(1971)^{4}$. However all these equations were obtained by experiment with specified particles or from a small number of data within a certain limited range. There are few equations on systematic experiments.

As a comparatively applicable equation among these, Doig and Roper's equation is mentioned, which was obtained by analyzing the data of Segler ${ }^{8)}$, Barth, Zenz $^{12)}$ and others. Correlating the present data with the equation, a large deviation was found to exist between the calculated and experimental values.

In Fig. 9, Barth and Segler's data of wheat in conduit ranging from 20 to $420 \mathrm{~mm}$ diameter are shown in comparison with our experimental results. The dotted line in Fig. 9 represents Barth's equation $\left(m_{c}=0.31 \times\left(F r_{c} / 10\right)^{4}\right)$ normalized by using properties of wheat. This figure shows that Eq. (13) covers Barth's equation.

The other equations were also compared with our data, but none of them correlated our data satisfactorily. This is due to the above-mentioned reasons.

\section{Conclusion}

1) The minimum transport velocity for horizontal pneumatic conveying of granular particles can be satisfactorily correlated by Eq. (13).

2) Saltation velocity, at which the flow pattern changed from suspension flow to sliding flow, was carrelated by Eq. (12).

These equations may be used for the horizontal pneumatic conveying of granular particles in the following range; $0.29 \leq d_{p} \leq 2.6[\mathrm{~mm}], 1.0 \leq \rho_{p} \leq 8.7$ $\left[\mathrm{g} / \mathrm{cm}^{3}\right], 5 \leq F r \leq 30$.

\begin{tabular}{|c|c|c|}
\hline \multicolumn{3}{|c|}{ Nomenclature } \\
\hline$A$ & $=$ cross-sectional area of pipe & {$\left[\mathrm{m}^{2}\right]$} \\
\hline$c_{0}$ & $=$ constant in Eq. (4) & {$[-]$} \\
\hline$D$ & $=$ pipe diameter & {$[\mathrm{m}]$} \\
\hline$d_{p}$ & $=$ particle diameter & [m] \\
\hline$F r$ & $=$ Froude number, $u_{a} / \sqrt{g D}$ & {$[-]$} \\
\hline$F r_{p}$ & $=$ "particle" Froude number, $u_{t} / \sqrt{g d_{p}}$ & {$[-]$} \\
\hline$F r_{t}$ & $=$ "characteristic" Froude number, $u_{t} / \sqrt{g L}$ & {$[-]$} \\
\hline$f_{a}$ & $=$ friction factor due to air alone & {$[-]$} \\
\hline$f_{p}$ & $=$ friction factor due to solids friction & {$[-]$} \\
\hline$G_{a}$ & $=$ air flow rate & {$[\mathrm{kg} / \mathrm{sec}]$} \\
\hline$G_{p}$ & $=$ solids flow rate & {$[\mathrm{kg} / \mathrm{sec}]$} \\
\hline$g$ & $=$ gravitational acceleration & {$\left[\mathrm{m} / \mathrm{sec}^{2}\right]$} \\
\hline$g_{c}$ & $=$ gravitational conversion factor & $\left./ \mathrm{Kg} \cdot \mathrm{sec}^{2}\right]$ \\
\hline$L$ & $=$ pipe length & {$[\mathrm{m}]$} \\
\hline$m$ & $=$ mass flow ratio, $G_{p} / G_{a}$ & {$[-]$} \\
\hline$\Delta P_{a}$ & $=$ pressure drop due to friction of air & {$\left[\mathrm{Kg} / \mathrm{m}^{2}\right]$} \\
\hline$\Delta P_{h}$ & $=$ pressure drop due to gravity of solids & {$\left[\mathrm{Kg} / \mathrm{m}^{2}\right]$} \\
\hline$\Delta P_{s f}$ & $=$ pressure drop due to solids friction & {$\left[\mathrm{Kg} / \mathrm{m}^{2}\right]$} \\
\hline$\Delta P_{T}$ & $=$ total pressure drop & {$\left[\mathrm{Kg} / \mathrm{m}^{2}\right]$} \\
\hline$Q_{a}$ & $=$ volumetric air flow rate & {$\left[\mathrm{m}^{3} / \mathrm{sec}\right]$} \\
\hline$u_{a}, u_{p}$ & $\begin{array}{l}=\text { air and particles mean velocity, } \\
\text { respectively }\end{array}$ & {$[\mathrm{m} / \mathrm{sec}]$} \\
\hline$u_{t}$ & $=$ terminal velocity of particle & {$[\mathrm{m} / \mathrm{sec}]$} \\
\hline$v_{p}$ & $=$ falling velocity of particle in pipe & {$[\mathrm{m} / \mathrm{sec}]$} \\
\hline$\rho_{a}, \rho_{p}$ & $=$ density of air and solids, respectively & {$\left[\mathrm{kg} / \mathrm{m}^{3}\right]$} \\
\hline$\rho_{d s}$ & $\begin{array}{l}=\text { dispersed density of gas-solids two-phase } \\
\text { flow }\end{array}$ & {$\left[\mathrm{kg} / \mathrm{m}^{3}\right]$} \\
\hline$\varphi$ & $=$ velocity ratio, $u_{p} / u_{a}$ & {$[-]$} \\
\hline
\end{tabular}

$\langle$ Subscripts〉

$c=$ corresponds to minimum transport velocity

$s \quad=$ corresponds to saltation point

\section{Literature Cited}

1) Barth, W.: Chem. Ing. Tech., 26, 29 (1954)

2) Bohnet, M.: VDI-Forschungsheft, 507 (1965)

3) Doig, I. D. and G. H. Roper: Australian Chem. Eng., 4, 9 (1963)

4) Duckworth, R. A.: Proceedings of First International Conference on the Pneumatic Transport of Solids in Pipe, R2-25 (1971)

5) Guenther, W.: Dissertation, T. H. Karlsruhe, West Germany (1957)

6) Jotaki, T. and F. Nishioka: "Funryūtai no kūki yusō", p. 63, Nikkan-Kōgyō (1961)

7) Rose, H. E. and R. A. Duckworth: Proceedings of the I. Chem. E.-VTG/VDI Joint Meetings, p. 53 (1968)

8) Segler, G.: Untersuchungen an Körnergebläsen und Grundlagen für ihre Berechung, Mannheim (1934)

9) Siegel, W.: VDI-Forschungsheft, 583 (1970)

10) Thomas, D. G.: AIChE J., 8, 373 (1962)

11) Welschof, G.: VDI-Forschungsheft, 492 (1962)

12) Zenz, F. A.: Petroleum Refiner, 36, 133 (1957) 